ORIGINAL ARTICLE / ARTIGO ORIGINAL

\title{
Medicine package inserts from the users' perspective: are they read and understood?
}

\author{
Bulas de medicamentos sob a perspectiva dos usuários: \\ elas são lidas e compreendidas?
}

\begin{abstract}
Tatiane da Silva Dal Pizzol' (1D, Cassia Garcia Moraes"I (D), Paulo Sérgio Dourado Arrais III (D), Andréa Dâmaso Bertoldiv (D), Luiz Roberto Ramos ${ }^{\mathrm{V}}$ (D), Mareni Rocha Farias ${ }^{\mathrm{Vl}}$ (D), Maria Auxiliadora Oliveira ${ }^{\mathrm{VII}}$ (D), Noemia Urruth Leão Tavares ${ }^{\mathrm{VIII}}$ (D), Vera Lucia Luiza ${ }^{\mathrm{IX}} \mathbb{( D D}^{\text {(D) }}$ Sotero Serrate Mengue ${ }^{x}$ (D)
\end{abstract}

\begin{abstract}
Introduction: The written information on medicines has been acknowledged as an important tool for health education. Objective: To analyze the use and understanding of medicine package inserts by users and assess sociodemographic and medical factors associated with their comprehension. Method: Data in this analysis are part of the PNAUM National Survey - a cross-sectional population-based study conducted in Brazil. Descriptive statistics and the Pearson $\chi^{2}$ tests were performed to compare proportions between sociodemographic and medical characteristics, as well as use and understanding of medicine package inserts. Results: A total of 28.427 individuals responded to questions related to medicine package inserts. From these, $59.6 \%(95 \%$ CI $57.7-61.5)$ said they usually read the inserts, and $98.4 \%$ (95\%CI $98.0-98.8)$ considered them necessary. Among people who read the medicine package inserts, more than half indicated difficulties with legibility $(57.4 \%$; $95 \%$ CI 55,2 - 59,6) and readability $(54.1 \%$; 95\%CI 52.1 - 56.1). People from a lower education level reported greater difficulty in understanding them. Conclusion: The larger portion of the population usually read medicine package inserts. Nevertheless, people have difficulty in reading and understanding them.
\end{abstract}

Keywords: Medicine package inserts. Health communication. Readability.

'Medicines Production and Control Department, Pharmacy College and Post Graduate Program in Epidemiology, Universidade Federal do Rio Grande do Sul - Porto Alegre, RS, Brazil.

"Moinhos de Vento Hospital - Porto Alegre, RS, Brazil

I'Pharmacy Department, Pharmacy, Odontology and Nursering College, Universidade Federal do Ceará - Fortaleza,CE, Brazil.

IvSocial Medicine Department. Medicine College, Universidade Federal de Pelotas - Pelotas, RS, Brazil.

vPreventive Medicine Department, Escola Paulista de Medicina, Universidade Federal de São Paulo - São Paulo, SP, Brazil.

viPharmaceutical Sciences Department, Health Sciences Center, Universidade Federal de Santa Catarina - Florianópolis, SC, Brazil.

v"Escola Nacional de Saúde Pública Sérgio Arouca, Fundação Oswaldo Cruz - Rio de Janeiro, RJ, Brazil.

VIIIPharmacy Department. Health Sciences College, Universidade de Brasília - Brasília, DF, Brazil.

xEscola Nacional de Saúde Pública Sérgio Arouca, Fundação Oswaldo Cruz - Rio de Janeiro, RJ, Brazil.

xpost Graduate Program in Epidemiology of Universidade Federal do Rio Grande do Sul - Porto Alegre, RS, Brazil.

Corresponding author: Tatiane da Silva Dal Plzzol. Avenida Ipiranga, 2752, sala 203, CEP: 90610-000, Porto Alegre, RS, Brazil.

E-mail: tatiane.silva@ufrgs.br

Conflict of interests: nothing to declare - Financial support: Brazilian Ministry of Health through the Secretariat of Science, Technology and Strategic Inputs - SCTIE (Process 25000.111834/2). 
RESUMO: Introdução: A informação escrita sobre medicamentos tem sido reconhecida como uma ferramenta importante para a educação em saúde. Objetivo: Analisar o uso e compreensão de bulas de medicamentos pelos usuários e avaliar fatores sociodemográficos e médicos associados ao seu uso e compreensão. Método: Os dados nesta análise fazem parte da PNAUM - um estudo transversal de base populacional realizado nas cinco regiões brasileiras. Estatísticas descritivas e teste de $\chi^{2}$ de Pearson foram utilizados para comparar proporções entre características sociodemográficas e médicas, uso e compreensão das bulas. Resultados: Um total de 28.427 indivíduos responderam a questões relativas a bulas. Desse total, 59,6\% (IC95\% 57,7 - 61,5) responderam que geralmente leem as bulas e $98,4 \%$ (IC95\% 98,0 - 98,8) as consideraram necessárias. Entre as pessoas que leram as bulas, mais da metade indicou dificuldades de legibilidade (57,4\%; IC95\% 55,2 - 59,6) e de leiturabilidade $(54,1 \%$; IC95\% 52,1 - 56,1) das bulas. As pessoas com menos educação relataram maior dificuldade em compreendê-las. Conclusões: A maioria da população tem o costume de ler as bulas, no entanto as pessoas consideram-nas difíceis de ler e compreender.

Palavras-chave: Bulas de medicamentos. Comunicação em saúde. Compreensão.

\section{INTRODUCTION}

In several countries, the written information on medicines has been acknowledged as an important tool for health education, and their drug regulatory agencies have established guidelines and standards for the production and delivery of medicine package inserts (MPI).

In European Union, all medicinal products placed on the market must be accompanied by MPI containing text that is demonstrably clear and simple ${ }^{1,2}$. In the United States there are three types of written materials that accompany medicines, of which two (Medication Guides and Patient package inserts) are developed by the pharmaceutical industry, regulated and approved by the Food and Drug Administration (FDA). A third format (Consumer medication information) is developed by commercial providers, and it is distributed in pharmacies and not reviewed by the FDA ${ }^{2-4}$. In Brazil, MPI is the same for all products registered as medicines. The manufacturer produces one MPI for the health professional and another one for the patient, and the National Agency of Sanitary Surveillance (ANVISA) is responsible for the approval of these materials' format and content ${ }^{5}$.

Due to the complexity and importance of medicine information, technical standards and guidelines that establish the format and content have been improved in many countries to make the leaflet more attractive and understandable to the user. Among several factors, the proper use of the medicine package insert depends on its readability and the user's ability to read, understand and use the information contained therein for the rational use of the medicine ${ }^{6}$. Some studies have reported that health literacy is outstanding among the individual factors related to the difficulties in understanding the information contained in the $\mathrm{MPI}^{7,8}$. 
Evaluating aspects related to the use and understanding of the MPI from the user's point of view may help to improve this document as an educational material. This study aimed to describe its use and understanding by users and to evaluate the associated sociodemographic factors.

\section{METHOD}

The data of the present analysis are part of the National Survey on Access, Use and Promotion of Rational Use of Medicines (PNAUM), a cross-sectional population-based study conducted in Brazil. The studied population consisted of people living in permanent private households in the urban area of the five Brazilian regions. We used a questionnaire containing 11 blocks, answered by the participants at their residence, by using an electronic device for data collection, storage and transmission ${ }^{9}$.

The sample included eight demographic domains (different genders and age ranges) that were replicated for each of the five Brazilian geographic regions, resulting in 40 domains. As a result, the sample size calculated was 960 per domain, totaling 38,400 interviewees. The sample was selected in three stages: municipality (primary unit), census tract and domicile. Its process was complex and resulted in a sample that guaranteed national representativeness. Sample composition, procedures and other methodological details of PNAUM are available in the research's methodological article ${ }^{9}$.

The use and understanding of the MPI by the participants was investigated in a specific block. In the pre-testing phase, some questions were initially asked openly and in subsequent stages transformed into multiple choice questions. This block was answered only by literate individuals; were aged 15 years or older; and did not fit into the concept of "incapable people" (people unable to communicate or provide information about themselves due to physical or mental illness, speech deprivation or lack of judgment to answer the questions).

The use of MPIs was evaluated by means of the dichotomous question: "(a) Do you usually read the MPI of the medicines you use?". If not, the participants were asked why they did not read it. Participants who answered affirmatively to this question were asked subsequent questions about legibility ("Seeing what is written in the medicine package insert, it is", with the following alternative answers: 'very difficult', 'quite difficult', 'not difficult'); and on the MPI's readability ("Understanding what is written in MPI is", followed by following alternative answers: 'very difficult', 'quite difficult', and 'not difficult').

Participants who reported having the habit of reading the MPI were asked to give their opinion about the need for it and the reasons why they considered them to be necessary. Finally, participants were asked if they had stopped taking some medicine after reading its MPI.

The main outcome variables analyzed were:

- habit of reading the MPI (yes / no);

- difficulty in understanding the MPI ("No", for those who answered that understanding the MPI was not difficult; and "yes", for those who answered that understanding it was very difficult or quite difficult). 
The demographic and socioeconomic characteristics analyzed were: gender (female / male), schooling (did not go to school, 1 to 8 years of schooling and more than 8 years of schooling), age (15 to 19 years, 20 to 39 years, 40 to 59 years and $>60$ years), major Brazilian geographical regions (North, Northeast, Southeast, South and Midwest) and economic classification by the Brazilian Economic Classification Criterion (CCEB) of Brazilian Association of Survey Companies (ABEP). This classification evaluates the amount of goods purchased and the educational level of household heads by scoring from zero to forty-six, and the respondents were distributed into eight economic classes (A1, A2, B1, B2, C1, C2, D and E).

The medical variables analyzed were: use of medication (use of at least one medication for chronic disease, occasional or contraceptive use) (yes / no); use of medicines for chronic diseases (use of at least one medication for chronic diseases) (yes / no); and use of medications for acute / occasional diseases (use of at least one drug to treat acute signs, symptoms and conditions) (yes/no).

Descriptive analyses were performed and the results expressed in frequency and $95 \%$ confidence interval $(95 \% \mathrm{CI})$. Pearson's $\chi^{2}$ test was used to compare proportions between sociodemographic characteristics and the use and understanding of medicine package inserts, with a P-value $<0.05$ being considered statistically significant.

These data were stored in SPSS software, version 18.0 for Windows (SPSS Inc., Chicago, IL, USA), by using the appropriate set of commands for complex samples' analysis and guaranteeing the necessary weighting considering the sample's design.

The project was approved by the National Research Ethics Commission (CONEP). Participants were interviewed only after we had obtained their permission, by means of the Term of Free and Informed Consent signed by both the researcher and the participant.

\section{RESULTS}

The initial sample in the PNAUM was 41,433 individuals, of whom 28,427 met the inclusion criteria to answer the questions related to the medication package leaflets (literate individuals, aged 15 years or older and able), by whom the sample analyzed in this study was composed.

From this total, $59.6 \%(95 \%$ CI $57.7-61.5)$ stated that they usually read the MPI. The reasons for not reading MPI are shown in Table 1 . The non-use of medication was the main reason cited (40\%), followed by reading difficulty (31\%) and size (extension) of the material (20\%).

Among those who read the MPI, more than half found it difficult to see $(57.4 \%$; $95 \% \mathrm{CI}$ $55,2-59,6)$ and understand $(54.1 \%$; 95\% CI 52.1 - 56.1) what was written in it (Table 2).

After reading the MPI, $25.0 \%(95 \%$ CI $23.5-26.7)$ of the interviewees stopped taking some of the medicines. Despite the fact that almost half the respondents did not read the MPI, 98.4\% (95\%CI $98.0-98.8)$ of the individuals who answered this questionnaire considered it to be necessary. The main reasons of this opinion were related to the presence of information about indication (79.6\%) and contraindications (75.4\%) (Table 3 ). 
The use of MPIs according to sociodemographic and medical characteristics is presented in Table 4. There was no difference in its use when analyzed by gender and age group. People with lower schooling and purchasing power reported reading fewer MPIs than people with higher education and of higher economic class. MPIs were read by a higher number of people who reported use of medication for acute/occasional condition

Table 1. Medicine users' habit of reading medicine package inserts $(n=28,427)$ and reasons for not reading them*.

$\%(95 \% \mathrm{Cl})$

Habit of Reading the medicine package inserts

\begin{tabular}{l|c}
\hline Yes $(\mathrm{n}=17.244)$ & $59.6(57.7-61.5)$ \\
\hline No $(\mathrm{n}=11.183)$ & $40.4(38.5-42.3)$ \\
\hline Reasons for not reading the medicine package inserts* & \\
\hline I do not use medicines & 40 \\
\hline They are difficult to read & 31 \\
\hline They are too long & 20 \\
\hline They confuse & 15 \\
\hline Trust the doctor & 2 \\
\hline Do not see/ Do not read & 2 \\
\hline Others & 6 \\
\hline
\end{tabular}

*The total exceeds $100 \%$ because participants could choose more than one answer option. It was not possible to calculate the $\mathrm{Cl}$ for proportions because it is a multiple choice question. Considering the sampling plan of the PNAUM, only the procedure for the calculation of the confidence interval for independent samples has been implemented in SPSS; $95 \% \mathrm{Cl}$ : interval of confidence of $95 \%$.

Table 2. Difficulty of legibility and readability of the medicine package inserts referred to by the users.

\section{$95 \% \mathrm{Cl}$}

Difficulty with seeing the print in medicine package inserts (legibility) $(n=17,244)$

\begin{tabular}{|l|l|l}
\hline Very difficult & 25.2 & $23.4-27.1$ \\
\hline A little difficult & 32.2 & $30.7-33.8$ \\
\hline Is not difficult & 42.6 & $40.4-44.8$ \\
\hline
\end{tabular}

Difficulty in understanding the medicine package inserts (readability) $(n=17,244)$

\begin{tabular}{|l|l|l|}
\hline Very difficult & 17.2 & $15.7-18.9$ \\
\hline A little difficult & 36.9 & $35.4-38.5$ \\
\hline Is not difficult & 45.9 & $43.8-47.9$ \\
\hline
\end{tabular}

$95 \% \mathrm{Cl}$ : interval of confidence of $95 \%$. 
than by those who did not use medication for this type of condition. Whereas, between the individuals who made continuous use of medicines and those who did not use them, there was no difference in these numbers. Participants from the Northeast region usually read medicine package inserts more frequently than participants from other regions. The association between sociodemographic and medical characteristics and the difficulty in understanding the MPI is presented in Table 5. People with fewer years of study declared more difficulty in understanding the information presented in it than those with more.

\section{DISCUSSION}

According to a previous study conducted in 1998 and published in 2000 by the authors of this article ${ }^{10}$, patients considered the MPI the most important source of information about medicines after medical prescription. Almost 20 years later, even with all technological advances in the media - internet, TV, computers, smartphones, tablets and others MPIs continued to be a prominent source of information among users, and most of the participants had the habit of reading them, according to the results of our study. On the other hand, a significant number of interviewees reported difficulties in reading the MPI, as they considered them illegible, long and confusing. Among the individuals with less schooling, the difficulty was greater. In agreement with other studies, our results suggested that MPIs were more than a legal obligation to be taken care by pharmaceutical manufactures because it was an important information tool for the users ${ }^{11-13}$.

According to reviews on the subject, the most important information about medicines, from the user's point of view, were: information about indication, potential adverse effects, dose and dosage ${ }^{14,15}$. In our study, participants emphasized MPI's importance for providing them information on indications and contraindications. In Brazilian MPIs, these items are presented as answers to the questions "What is this medicine for?" and "When should I not use this medicine?", respectively. This finding may indicate that people use the MPI to seek information on the medical condition to be treated, to confirm or supplement the

Table 3. Reasons why users considered medicine package inserts to be necessary*.

\begin{tabular}{l|c}
\hline & $\%$ \\
\hline Show indications for use of the medicine & 79.6 \\
\hline Show contraindications for the medicine & 75.4 \\
\hline Show information about the composition of the medicine & 53.3 \\
\hline Show information about the dosage and administration of the medicine & 49.6 \\
\hline Other reasons & 1.6 \\
\hline *The total exceeds $100 \%$ because participants could choose more than one answer option. It was not possible to \\
calculate the Cl for proportions because it is a multiple choice question. Considering the sampling plan of the PNAUM, \\
only the procedure for the calculation of the confidence interval for independent samples has been implemented in SPSS.
\end{tabular}


Table 4. Association of sociodemographic and medical characteristics, according to the habit of reading medicine package inserts.

\begin{tabular}{|c|c|c|c|c|c|}
\hline \multirow[t]{2}{*}{ Variables } & \multicolumn{2}{|c|}{$\begin{array}{c}\text { Usually reads medicine } \\
\text { package inserts }\end{array}$} & \multicolumn{2}{|c|}{$\begin{array}{c}\text { Does not usually read } \\
\text { medicine package inserts }\end{array}$} & \multirow{2}{*}{$\mathrm{p}$-value } \\
\hline & $\%$ & $95 \% \mathrm{Cl}$ & $\%$ & $95 \% \mathrm{Cl}$ & \\
\hline Total & 59.6 & $57.7-61.5$ & 40.4 & $38.5-42.3$ & \\
\hline \multicolumn{6}{|l|}{ Gender } \\
\hline Female & 59.4 & $57.3-61.4$ & 40.6 & $38.6-42.7$ & \multirow{2}{*}{0.660} \\
\hline Male & 59.9 & $57.5-62.2$ & 40.1 & $37.8-42.5$ & \\
\hline \multicolumn{6}{|l|}{ Age Group } \\
\hline 15 to 19 & 59.4 & $55.2-63.5$ & 40.6 & $36.5-44.8$ & \multirow{4}{*}{0.186} \\
\hline 20 to 39 & 60.7 & $58.5-62.8$ & 39.3 & $37.2-41.5$ & \\
\hline 40 to 59 & 58.2 & $55.9-60.4$ & 41.8 & $39.6-44.1$ & \\
\hline$\geq 60$ & 60.0 & $57.5-62.4$ & 40.0 & $37.6-42.5$ & \\
\hline \multicolumn{6}{|l|}{ Schooling } \\
\hline Never studied & 17.9 & $11.3-27.1$ & 82.1 & $72.9-88.7$ & \multirow{3}{*}{$0.000^{*}$} \\
\hline 1 to 8 years of schooling & 50.8 & $48.7-52.9$ & 49.2 & $47.1-51.3$ & \\
\hline Over 8 years of schooling & 69.5 & $67.2-71.6$ & 30.5 & $28.4-32.8$ & \\
\hline \multicolumn{6}{|l|}{ Region } \\
\hline North & 64.1 & $60.5-67.6$ & 35.9 & $32.4-39.5$ & \multirow{5}{*}{$0.000^{*}$} \\
\hline Northeast & 66.5 & $64.6-68.4$ & 33.5 & $31.6-35.4$ & \\
\hline Southeast & 55.6 & $52.2-59.0$ & 44.4 & $41.0-47.8$ & \\
\hline South & 61.6 & $58.9-64.2$ & 38.4 & $35.8-41.1$ & \\
\hline Midwest & 57.8 & $54.7-60.9$ & 42.2 & $39.1-45.3$ & \\
\hline \multicolumn{6}{|l|}{ Economic class (ABEP) } \\
\hline$A / B$ & 62.4 & $59.4-65.3$ & 37.6 & $34.7-40.6$ & \multirow{3}{*}{$0.000^{*}$} \\
\hline C & 60.1 & $57.9-62.3$ & 39.9 & $37.7-42.1$ & \\
\hline $\mathrm{D} / \mathrm{E}$ & 54.8 & $52.1-57.4$ & 45.2 & $42.6-47.9$ & \\
\hline \multicolumn{6}{|l|}{ Medicine use } \\
\hline Yes & 60.7 & $58.8-62.6$ & 39.3 & $37.4-41.2$ & \multirow{2}{*}{$0.029 *$} \\
\hline No & 58.4 & $56.0-60.8$ & 41.6 & $39.2-44.0$ & \\
\hline \multicolumn{6}{|l|}{ Continuous use of medication } \\
\hline Yes & 59.6 & $57.3-61.8$ & 40.4 & $38.2-42.7$ & \multirow{2}{*}{0.956} \\
\hline No & 59.6 & $57.7-61.6$ & 40.4 & $38.4-42.3$ & \\
\hline \multicolumn{6}{|l|}{ Eventual use of medication } \\
\hline Yes & 62.3 & $60.4-64.2$ & 37.7 & $35.8-39.6$ & \multirow{2}{*}{0.0001 * } \\
\hline No & 58.1 & $55.8-60.4$ & 41.9 & $39.6-44.2$ & \\
\hline
\end{tabular}

${ }^{*} \chi^{2}$ test, $p<0.05 ; 95 \% \mathrm{Cl}$ : interval of confidence of 95\%; ABEP: Brazilian Association of Survey Companies. 
Table 5. Association of sociodemographic and medical characteristics and difficulty in understanding the medicine package insert.

\begin{tabular}{|c|c|c|c|c|c|}
\hline \multirow{3}{*}{ Variables } & \multicolumn{4}{|c|}{ Difficulty in understanding the medicine package insert } & \multirow{3}{*}{ p-value* } \\
\hline & \multicolumn{2}{|c|}{ Yes } & \multicolumn{2}{|c|}{ No } & \\
\hline & $\%$ & $95 \% \mathrm{Cl}$ & $\%$ & $95 \% \mathrm{Cl}$ & \\
\hline Total & 54.1 & $52.1-56.1$ & 45.9 & $43.9-47.9$ & \\
\hline \multicolumn{6}{|l|}{ Gender } \\
\hline Female & 53.1 & $50.5-55.6$ & 46.9 & $44.4-49.5$ & \multirow{2}{*}{0.125} \\
\hline Male & 55.1 & $52.8-57.4$ & 44.9 & $42.6-47.2$ & \\
\hline \multicolumn{6}{|l|}{ Age Group } \\
\hline 15 to 19 & 50.8 & $44.9-56.6$ & 49.2 & $43.4-55.1$ & \multirow{4}{*}{0.147} \\
\hline 20 to 39 & 55.8 & $53.3-58.4$ & 44.2 & $41.6-46.7$ & \\
\hline 40 to 59 & 53.2 & $50.7-55.7$ & 46.8 & $44.3-49.3$ & \\
\hline$\geq 60$ & 53.8 & $50.7-56.9$ & 46.2 & $43.1-49.3$ & \\
\hline \multicolumn{6}{|l|}{ Schooling } \\
\hline Never studied & 86.0 & $71.4-93.8$ & 14.0 & $6.2-28.6$ & \multirow{3}{*}{$0.000^{*}$} \\
\hline 1 to 8 years of schooling & 63.2 & $60.5-65.8$ & 36.8 & $34.2-39.5$ & \\
\hline Over 8 years of schooling & 47.2 & $44.7-49.6$ & 52.8 & $50.4-55.3$ & \\
\hline \multicolumn{6}{|l|}{ Region } \\
\hline North & 55.1 & $51.5-58.6$ & 44.9 & $41.4-48.5$ & \multirow{5}{*}{0.051} \\
\hline Northeast & 57.6 & $54.8-60.4$ & 42.4 & $39.6-45.2$ & \\
\hline Southeast & 51.9 & $48.0-55.9$ & 48.1 & $44.1-52.0$ & \\
\hline South & 53.4 & $50.3-56.5$ & 46.6 & $43.5-49.7$ & \\
\hline Midwest & 57.0 & $53.2-60.8$ & 43.0 & $39.2-46.8$ & \\
\hline \multicolumn{6}{|l|}{ Economic class (ABEP) } \\
\hline$A / B$ & 52.4 & $49.2-55.5$ & 47.6 & $44.5-50.8$ & \multirow{3}{*}{0.329} \\
\hline C & 54.6 & $52.3-57.0$ & 45.4 & $43.0-47.7$ & \\
\hline$D / E$ & 55.3 & $51.4-59.1$ & 44.7 & $40.9-48.6$ & \\
\hline \multicolumn{6}{|l|}{ Medicine use } \\
\hline Yes & 54.8 & $52.4-57.1$ & 45.2 & $42.9-47.6$ & \multirow{2}{*}{0.360} \\
\hline No & 53.5 & $50.9-56.0$ & 46.5 & $44.0-49.1$ & \\
\hline \multicolumn{6}{|l|}{ Continuous use of medication } \\
\hline Yes & 53.9 & $51.2-56.6$ & 46.100 & $43.4-48.8$ & \multirow{2}{*}{0.782} \\
\hline No & 54.3 & $52.0-56.5$ & 45.7 & $43.5-48.0$ & \\
\hline \multicolumn{6}{|l|}{ Eventual use of medication } \\
\hline Yes & 55.7 & $53.0-58.3$ & 44.3 & $41.7-47.0$ & \multirow{2}{*}{0.111} \\
\hline No & 53.3 & $50.9-55.6$ & 46.7 & $44.4-49.1$ & \\
\hline
\end{tabular}

${ }^{*} \chi^{2}$ test, $p<0.05 ; 95 \% \mathrm{Cl}$ : interval of confidence of 95\%; ABEP: Brazilian Association of Survey Companies. 
information received during their consultation with the doctor. Another possibility could be that people seek this information before self-medication, to ensure that the product meets their needs and has no contraindications for the intended use.

In this study we explored the concept of legibility and readability of MPIs and asked the users questions about the difficulty they had in seeing and understanding what was written in it. Most of the respondents stated that they had some degree of difficulty with these aspects. This reinforced results from previous studies that evaluated MPIs and other written materials, which were conducted by the researchers themselves ${ }^{13}$ or by consumers (patients and health professionals) $)^{1,4,16}$. Among the problems of legibility identified in the systematic review of Pires et al. ${ }^{1}$, the following were outstanding: insufficiently clear and simple texts, use of small print sizes and reduced number of illustrations.

The difficulty in reading and understanding the MPI was pointed out not only by the readers, but also by those who stated that they did not have the habit of reading them. Over $10 \%$ of non-readers mentioned long and confusing MPIs as reasons for not using, thus emphasizing the deficiencies in legibility and readability of these documents.

The habit of reading the MPI was directly related to some socioeconomic characteristics of the population. As the educational level declined, the MPI's reading decreased considerably. While most of those with a higher level of education reported that they read the MPI, fewer than a fifth of those who could read, but had not gone to school usually did it. Among those who usually read MPIs, the majority considered it to be difficult to understand, even among those with higher education. Some studies have shown the need for MPI's text to be simplified or clearer, suited to the users' level of schooling and health literacy ${ }^{1,6,17,18}$. MPIs were usually written at a high level of technical language, contained scientific jargons, making it much more difficult for those with a lower level of schooling or health literacy to understand them, as verified by Wolf et al. ${ }^{8}$ and Davis et al. ${ }^{7}$. This difficulty could lead to consumers losing interest or motivation to read them.

Attitudes and practices related to self-medication can explain the higher use of the MPI by individuals that reported use of medicines for acute/ occasional conditions. Consumers read the MPI of over-the-counter and other medicines used by self-medication to expand their understanding about a medicine's ingredients, relevant indication(s), directions for use and side effects ${ }^{16}$. Consequently, MPIs are probably one of the most important sources of drug-related information used for practices related to self-medication.

Some countries, in addition to the norms that establish the mandatory items, MPIs must contain guidelines for the adequate development of these materials, such Guideline on the readability of the labelling and package leaflet of medicinal products for human use, in European Union $^{19}$; and Investigating Consumer Medicine Information (I-CMI) Project, in Australia ${ }^{20}$. In Brazil, ANVISA has developed the Medication Labeling Guide with the aim of presenting principles and rules to be observed when writing the MPI to make it clearer, more concise and accessible to the user. Among the principles set out in this guide are the use of short sentences for long and complicated instructions, use of the active voice where appropriate, verbs instead of names in sentences; common language whenever possible and concrete and non-technical terms ${ }^{21}$. However, the manufacturers' obligation to test their leaflets among potential 
users has not yet been regulated, as in other countries. The European Medicines Agency (EMA), for example, states that MPI's readability must be verified by means of tests carried out in face-to-face interviews with at least 20 users (preferably from the population for which the medicine is intended).

In the present study we investigated the opinion of potential users of medications on the use, usefulness and understandability of MPIs in general, without questioning a particular medicine or specific items related to legibility and readability (such as letter size, text layout, presence of technical terms, etc.). In addition, individuals who had not recently used medicine may have had different motivations to answer the questionnaire in comparison with individuals who take medication regularly and may have needed to consult the MPI.

Readability tests, applied to medicine users by the industry, before the approval of the MPI by the regulatory agency, may be an alternative in the construction of a label model that is suitable for most of the population. Although MPIs are considered an important informative material in promoting the rational use of medications, their benefits may be compromised, as they do not present information that is adequate and easily understood by most medicine users.

In the present study, we found that most of the consumers interviewed had the habit of reading the MPIs, in accordance with previous studies (range 60-95\%) ${ }^{22}$. However, irrespective of the habit of reading, MPIs were considered difficult to read and understand. This problem was aggravated among the less educated individuals, drawing attention to an issue that continues to be a challenge to the government and society of several countries: the low level of schooling of a large part of the population, especially in developing countries, and the inadequate health literacy. In this sense, if people have a low level of schooling and difficulty in reading and understanding health texts, there is no simple MPI that will solve the problem. Particularly for people with a lower level of schooling or health literacy, it should be a complement, not a substitute for verbal information provided by health professionals ${ }^{14,22}$.

\section{CONCLUSION}

In conclusion, the larger portion of the Brazilian population usually reads the MPI. Nevertheless, people stated that they have difficulty in reading and understanding it, especially those of a lower educational level. Our findings can be useful for manufacturers and drug regulatory agencies to produce more readable and understandable MPIs to users. Efforts to improve their legibility and readability must be in line with efforts to improve education and other educational health actions that could minimize the difficulties of specific groups of the population, such as the elderly. In Brazil, MPIs available in audio, with an enlarged letter size or in braille have been regulated by sanitary legislation, offering an important alternative for people with visual impairment.

National Research Ethics Commission approval: CONEP, 398.131, dated 9/16/2013 


\section{REFERENCES}

1. Pires C, Vigário M, Cavaco A. Readability of medicinal package leaflets: A systematic review. Rev Saúde Pública 2015; 49; 4. https:// dx.doi.org/10.1590\% 2FS0034-8910.2015049005559

2. Luk A, Aslani P. Tools used to evaluate written medicine and health information: document and user perspectives. Health Educ Behav 2011; 38(4): 389-403. https: / / doi.org/10.1177/1090198110379576

3. Caldeira TR, Neves ERZ, Perini E. Evolução histórica das bulas de medicamentos no Brasil. Cad Saúde Pública 2008; 24(4): 737-43. http:/ / dx.doi.org/10.1590/ S0102-311X2008000400003

4. Shrank WH, Agnew-Blais J, Choudhry NK, Wolf MS, Kesselheim AS, Avorn J, et al. The Variability and Quality of Medication Container Labels. Arch Intern Med 2007; 167(16): 1760-5. https: / / doi.org/10.1001/ archinte.167.16.1760

5. Agência Nacional de Vigilância Sanitária. Resolução RDC $n^{\circ} 47$, de 8 de setembro de 2009. Brasil: Agência Nacional de Vigilância Sanitária; 2009 [cited Apr 25, 2017]. Available from: http://www.anvisa.gov.br/ medicamentos/bulas/rdc_47.pdf

6. Cavaco A, Santos AL. Avaliação da legibilidade de folhetos informativos e literacia em saúde. Rev Saúde Pública 2012; 46(5): 918-22. http: / / dx.doi.org/10.1590/ S0034-89102012000500019

7. Davis TC, Federman AD, Bass PF, Jackson RH, Middlebrooks M, Parker RM, et al. Improving patient understanding of prescription drug label instructions. J Gen Intern Med 2009; 24(1): 57-62. https:// doi. org/10.1007/s11606-008-0833-4

8. Wolf MS, Davis TC, Shrank W, Rapp DN, Bass PF, Connor UM, et al. To err is human: Patient misinterpretations of prescription drug label instructions. Patient Educ Couns 2007; 67(3): 293300. https: / / doi.org/10.1016/j.pec.2007.03.024

9. Mengue SS, Bertoldi AD, Boing AC, Tavares NUL, Pizzol T da SD, Oliveira MA, et al. National Survey on Access, Use and Promotion of Rational Use of Medicines (PNAUM): household survey component methods. Rev Saúde Pública 2016; 50(Suppl. 2): 4s. http://dx.doi.org/10.1590/ s1518-8787.2016050006156

10. Silva T da, Dal-Pizzol F, Bello CM, Mengue SS, Schenkel EP. Bulas de medicamentos e a informação adequada ao paciente. Rev Saúde Pública 2000; 34(2): 184-9. http:/ / dx.doi.org/10.1590/S0034-89102000000200013
11. Silva T, Schenkel EP, Mengue SS. Nível de informação a respeito de medicamentos prescritos a pacientes ambulatoriais de hospital universitário. Cad Saude Pública 2000; 16(2): 449-55. http:/ / dx.doi.org/10.1590/ S0102-311X2000000200015

12. Wolf MS, Davis TC, Tilson HH, Bass PF, Parker RM. Misunderstanding of prescription drug warning labels among patients with low literacy. Am J Health Pharm 2006; 63(11): 1048-55. https://doi.org/10.2146/ ajhp050469

13. Didonet J, Mengue SS. Drug labels: Are they a readable material? Patient Educ Couns 2008; 73(1): 141-5. https: / / doi.org/10.1016/j.pec.2008.05.004

14. Koo MM, Krass I, Aslani P. Factors Influencing Consumer Use of Written Drug Information. Ann Pharmacother 2003; 37(2): 259-67. https://doi. org/10.1177/106002800303700218

15. Raynor D, Blenkinsopp A, Knapp P, Grime J, Nicolson D, Pollock K, et al. A systematic review of quantitative and qualitative research on the role and effectiveness of written information available to patients about individual medicines. Health Technol Assess 2007; 11(5): iii, 1-160.

16. Tong V, Raynor DK, Aslani P. Design and comprehensibility of over-the-counter product labels and leaflets: a narrative review. Int J Clin Pharm 2014; 36(5): 865-72. https: / / doi.org/10.1007/s11096-014-9975-0

17. Pander Maat H, Lentz L. Improving the usability of patient information leaflets. Patient Educ Couns 2010; 80(1): 113-9. https://doi.org/10.1016/j. pec.2009.09.030

18. Fuchs J. The Way Forward in Package Insert User Tests From a CRO' s Perspective. Drug Inf J 2010; 44(2): 119-29. https:// doi.org/10.1177 $\% 2 \mathrm{~F} 009286151004400203$

19. European Commission Enterprise and Industry DirectorateGeneral. Guideline on the Readability of the Labelling and Package Leaflet of Medicinal Products for Human Use [Internet].2009[cited onNov 18,2017]. Available from:http:// ec.europa.eu/health/sites/health/files/files/eudralex/ vol-2/c/2009_01_12_readability_guidelinefinal_en.pdf

20. Australia. Australian Government Department of Health and Ageing. Investigating Consumer Medicine Information (I-CMI) Project [Internet]. [cited on Nov 18, 2017]. Available from: http:/ / 6cpa.com.au/wp-content/ uploads/Investigating-Consumer-Medicine-InformationI-CMI-Project-Full-Final-Report-Part-1.pdf 
21. Brazilian Health Regulatory Agency. Medication Labeling Guide [Internet]. Brazil: Brazilian Health Regulatory Agency [cited on Nov 18, 2017]. Available from: http:/ / portal.anvisa.gov.br/

22. Grime J, Blenkinsopp A, Raynor DK, Pollock K, Knapp P. The role and value of written information for patients about individual medicines: A systematic review. Health Expect 2007; 10(3): 286-98. https: / / doi. org/10.1111/j.1369-7625.2007.00454.x

Received on: 07/14/2017

Final version presented on: 11/18/2017

Approved on: 12/01/2017
Authors' Contributions: Design, analysis, interpretation of results and writing: Tatiane da Silva Dal Pizzol e Cassia Garcia Moraes. Critical review of content: Paulo Sérgio Dourado Arrais and Sotero Serrate Mengue All investigators of PNAUM Group (Andréa Dâmaso Bertoldi, Luiz Roberto Ramos, Mareni Rocha Farias, Maria Auxiliadora Oliveira, Noemia Urruth Leão Tavares, Paulo Sérgio Dourado Arrais, Sotero Serrate Mengue, Tatiane da Silva Dal Pizzol, Vera Lucia Luiza) took part in drafting the manuscript and approving the final version, and declare they are responsible for all aspects of the work, ensuring its accuracy and integrity. 